\title{
An autoradiographic study of gonadotrophin regulation of labelled glycoconjugates within preovulatory mouse follicles during the final stages of oocyte maturation, using $\left[{ }^{3} \mathrm{H}\right]$ glucosamine as the radioactive precursor
}

\author{
Ruth E. Fowler \\ Physiological Laboratory, University of Cambridge, Downing St, Cambridge CB2 3EG, U.K.
}

\begin{abstract}
Summary. Immature mice were treated with PMSG and hCG to induce follicular development and ovulation. $\left[{ }^{3} \mathrm{H}\right]$ Glucosamine was injected at the same time as the PMSG or $2 \mathrm{~h}$ before autopsy. The synthesis and distribution of labelled glycoconjugates within the preovulatory follicles was hormonally dependent. PMSG stimulated a rapid uptake of $\left[{ }^{3} \mathrm{H}\right]$ glucosamine into the zona pellucida and follicular fluid of the largest antral follicles although labelled macromolecules could not be demonstrated in any of the cellular components of these follicles. The injection of hCG stimulated a rapid incorporation of labelled macromolecules into the cellular components of the preovulatory follicle, namely into thecal, granulosa and especially the cumulus cells surrounding the oocyte. The density of labelled macromolecules within the follicular fluid also increased, while the specific and uniform labelling of the zona pellucida which was so characteristic of the period of PMSG stimulation changed. Between 4 and $8 \mathrm{~h}$ after the injection of $\mathrm{hCG}$, labelled glycoconjugates containing $\left[{ }^{3} \mathrm{H}\right]$ glucosamine, became increasingly associated with the outer surface of the zona pellucida and with the region of the egg plasma membrane, even in Graafian follicles not destined to ovulate. The change in distribution of labelled macromolecules on the zona surface may be a prerequisite for successful sperm-zona binding and the specific association of labelled glycoconjugates in the region of the egg plasma membrane may be involved in the preparation of the egg surface for sperm-egg interactions involving cortical granule exocytosis and the block to polyspermy.
\end{abstract}

Keywords: preovulatory mouse follicles; gonadotrophins; [ $\left.{ }^{3} \mathrm{H}\right] \mathrm{glucosamine;} \mathrm{glycoconjugates;}$ autoradiography

\section{Introduction}

Glycoconjugates are carbohydrate-rich macromolecules found in substantial quantities in the various components of the ovarian Graafian follicle. The follicular fluid, the secretions of the granulosa cells and those of the oocyte-cumulus complex are all rich in protein-carbohydrate complexes (Eppig, 1979, 1981; Ax \& Ryan, 1979a, b; Yanagishita et al., 1979, 1981; Yanagishita \& Haskall, 1979). They also form an integral part of the structure of the zona pellucida which surrounds the developing oocyte (Da Silva Sasso, 1959; Kang, 1974), containing neutral and acidic glycoconjugates with hyaluronic and sialic acid (Tadano \& Yamada, 1978), with positive reactions for terminal $N$-acety-D-galactosamine and terminal $\beta$-galactosyl residues.

The biosynthesis of glycoconjugates within the preovulatory follicles is almost certainly hormonally controlled, because their synthesis by cultured granulosa cells can be modified by gonadotrophins and steroid hormones (Yanagishita et al., 1981). Indeed, a series of cytochemical 
changes follows oocyte maturation, ovulation and fertilization (Fowler \& Grainge, 1985; Fowler et al., 1986; Shimizu \& Yamada, 1986). Changes that occur within the cumulus-oocyte complex are clearly significant for fertilization. The zona pellucida is an important site for sperm recognition, and a prerequisite for successful penetration is an interaction of the spermatozoon with the surface of the zona pellucida, leading to binding. This specific interaction is probably due to complementary components on apposing surfaces of the gametes (Shur \& Hall, 1982; Bleil \& Wassarman, 1983). The carbohydrate-binding components on the sperm surface (Ahuja, 1985) and the glycosylated nature of the major zona proteins (Bleil \& Wassarman, 1980; Shimizu et al., 1983) suggest that sperm-zona recognition may be determined by carbohydrate-carbohydrate interactions, carbohydrate-protein interactions or both. The sperm receptor activity of ZP3, one of the mouse zona pellucida glycoproteins, appears to be dependent on its carbohydrate component since sperm receptor activity was virtually unaffected by extensive proteolysis (Florman et al., 1984). It has been suggested that $N$-acetyglucosamine residues in the zona surface of mice mediate sperm binding (Shur \& Hall, 1982).

Autoradiography using labelled carbohydrates such as $\left[{ }^{3} \mathrm{H}\right]$ fucose and $\left[{ }^{3} \mathrm{H}\right]$ acetylglucosamine has been used to localize glycoproteins and glycosaminoglycans (GAG) within the various components of the ovary (Haddad \& Nagai, 1977; Oakberg \& Tyrell, 1975). The present study investigates the effect of gonadotrophins on the in-vivo synthesis of labelled glycoconjugates within the preovulatory follicle after an injection of $\left[{ }^{3} \mathrm{H}\right]$ glucosamine into immature mice at various times after treatment with PMSG and human chorionic gonadotrophin (hCG). The dynamic activity of the in-vivo system enabled us to localize the migration of newly synthesized macromolecules into the different components of the preovulatory follicle after hormone treatments which stimulate follicular development, oocyte maturation and ovulation.

\section{Materials and Methods}

PSMG induces the synchronous development of many Graafian follicles. After the injection of hCG, the sequence of events such as germinal vesicle breakdown, metaphase I, the formation and extrusion of the first polar body, metaphase II and finally ovulation can be timed with considerable accuracy (Edwards \& Gates, 1959).

MF1 albino mice, 3 weeks of age, were treated with PMSG followed after $40 \mathrm{~h}$ by an injection of hCG (Intervet Laboratories Ltd, Cambridge, U.K.). Of the 22 mice, 10 received an i.p. injection of $100 \mu \mathrm{Ci}$ D-[6- $\left.{ }^{3} \mathrm{H}\right] \mathrm{glucosamine}$ hydrochloride (Amersham International, Amersham, Bucks, U.K.: sp. act. $22.6 \mathrm{Ci} / \mathrm{mmol}$ ) in $0.1 \mathrm{ml} 0.9 \%(\mathrm{w} / \mathrm{v}$ ) NaCl at the time of the injection of PMSG. At 20,40,42, 48 and 51-53 h after the injection of PMSG, 2 mice were killed. The remaining 12 mice were injected with $\left[{ }^{3} \mathrm{H}\right]$ glucosamine $2 \mathrm{~h}$ before the time of autopsy. Two mice were autopsied at $2,40,42,44-46,48$ and $50 \mathrm{~h}$ after the injection of PMSG. A further 2 mice were injected with label during the period of hCG stimulation and autopsied 4 and $7 \mathrm{~h}$ later. At autopsy, both ovaries and oviducts were washed in isotonic saline $(0.85 \%)$ and then fixed in buffered formaldehyde-glutaraldehyde, as described by McDowell \& Trump (1976), containing $1.0 \%$ cetylpyridinium chloride.

The ovaries were processed as described previously (Fowler \& Grainge, 1985) and serial sections were cut at $5 \mu \mathrm{m}$. Tissue sections were deparaffinized, hydrated and coated with Kodak AR10 stripping film. After 4 weeks' exposure the sections were developed in Kodak D19, fixed in Johnson's fixol, washed and then air-dried. Sections were stained with Ehrlich's haematoxylin, air-dried and mounted in Dammar xylene. Radiolabelled glucosamine is incorporated into carbohydrate-protein complexes which include both proteoglycans and glycoproteins. Free $\left[{ }^{3} \mathrm{H}\right] \mathrm{glucosamine}$ not incorporated into macromolecules and that incorporated into glycolipids is extracted during the course of fixation and other treatments in preparation for autoradiography.

\section{Results}

\section{Injection of $\left[{ }^{3} \mathrm{H}\right]$ glucosamine at the time of the injection of $P M S G$}

The injection of PMSG into immature mice stimulated the development of many Graafian follicles. Changes in the intensity of label within the various components of the largest Graafian follicles are summarized in Table 1. After $20 \mathrm{~h}$ stimulation with PMSG, the highest intensity of label was found in the follicular fluid and the zona pellucida of the largest follicles (Fig. 1). Neither 


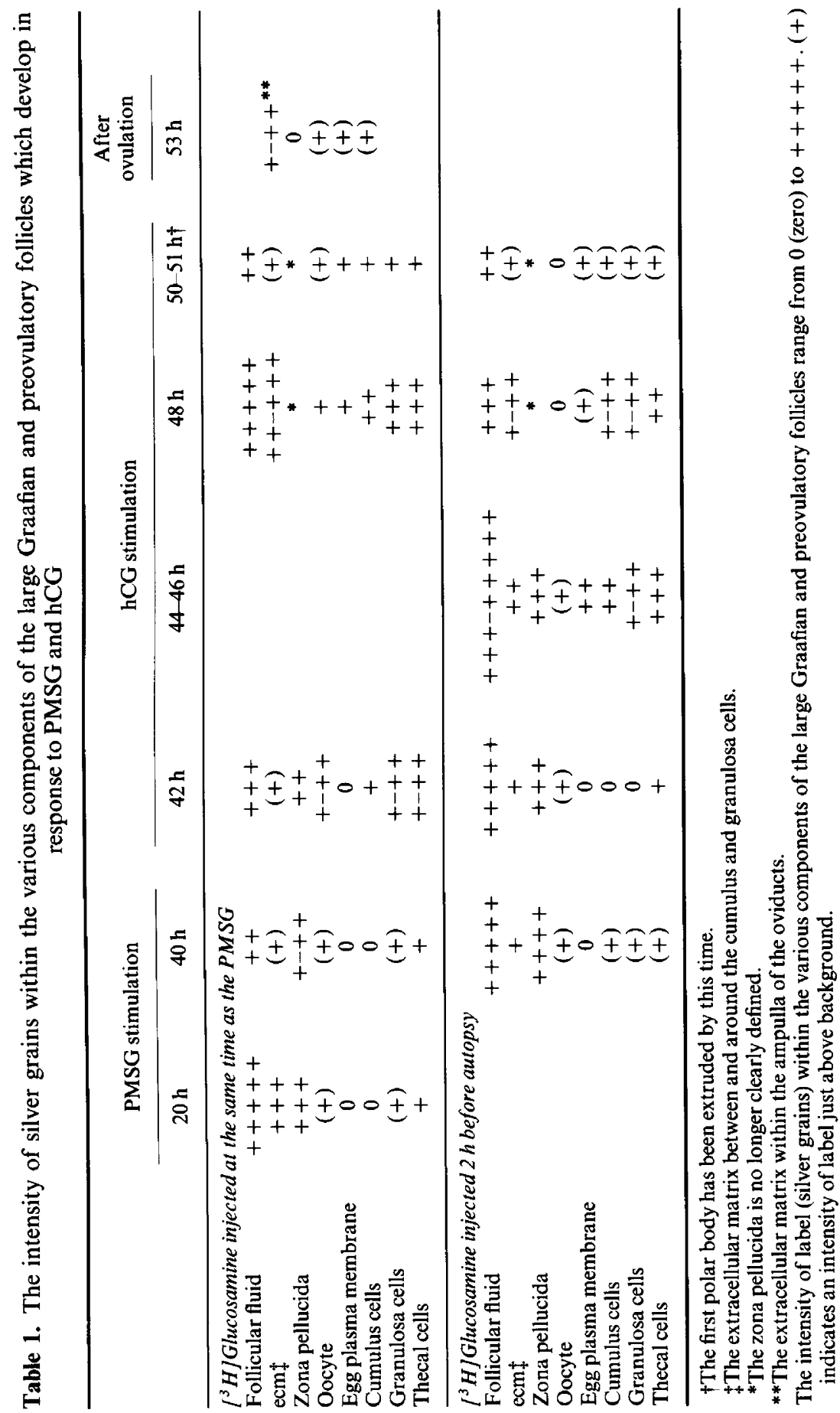




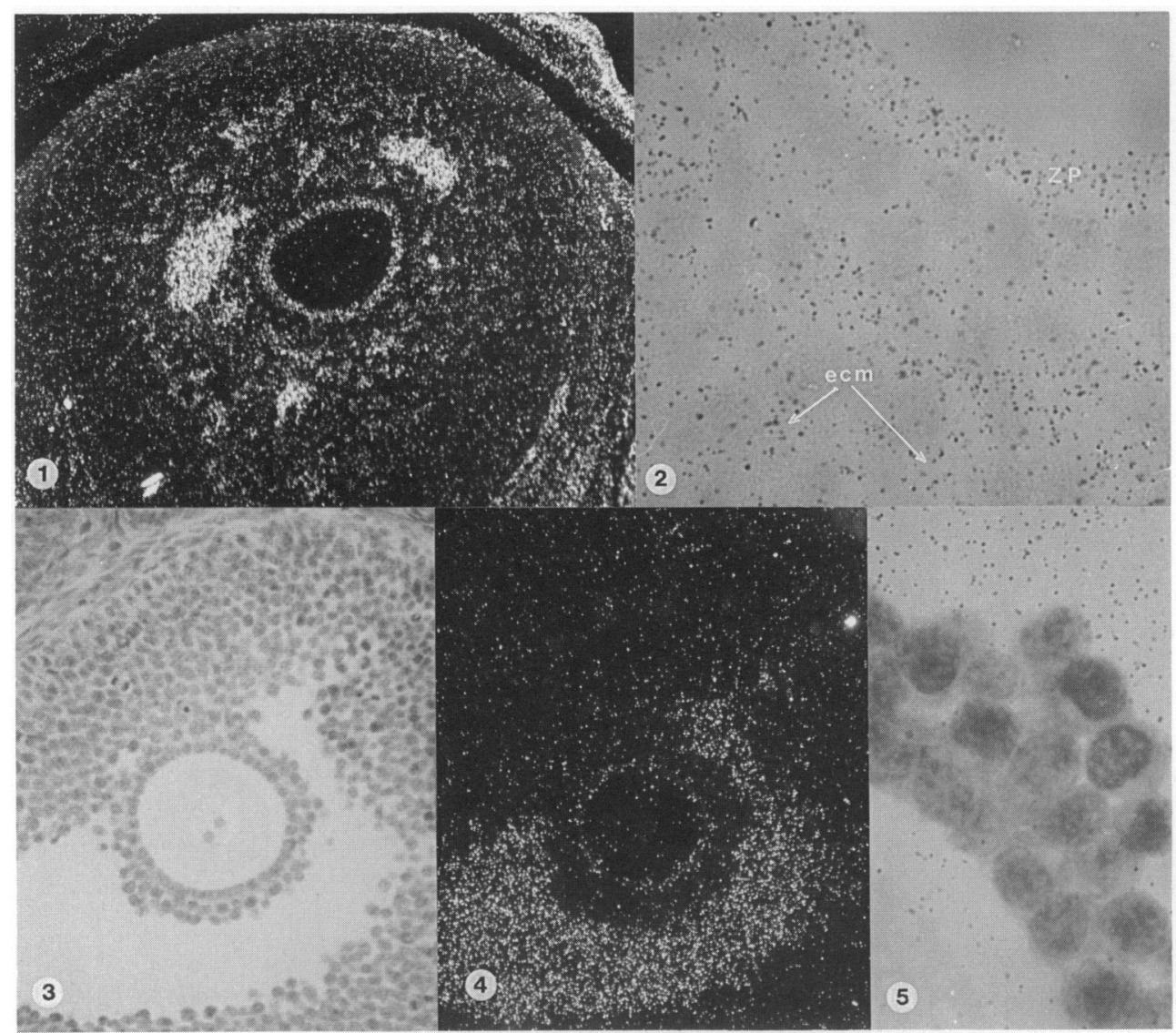

Figs 1-5. $\left[{ }^{3} \mathrm{H}\right]$ Glucosamine was injected at the same time as the PMSG.

Fig. 1. A large antral follicle developing in response to the injection of PMSG $20 \mathrm{~h}$ earlier. The labelling of the oocyte is only slightly above background levels. Dark field, $\times 245$.

Fig. 2. A high magnification photomicrograph showing labelling of the zona pellucida and the extracellular matrix surrounding the oocyte. Hacmatoxylin, $\times 1225$.

Fig. 3. A photomicrograph of a large antral follicle $40 \mathrm{~h}$ after the injection of PMSG. Note the tight adhesion of the cumulus cells around the oocyte surface. Hacmatoxylin, $\times 245$.

Fig. 4. An autoradiograph of Fig. 3. Dark field, $\times 245$.

Fig. 5. A high magnification of the labelling of the zona pellucida and cumulus cells surrounding the oocyte. Haematoxylin, $\times 1225$.

the cumulus cells surrounding the ovaries nor the granulosa cells appeared to be specifically labelled, the silver grains appearing to be confined to the extracellular matrix in and around the follicular cells (Fig. 2). After $40 \mathrm{~h}$ the size of the antrum had increased substantially although the egg still contained a germinal vesicle (Fig. 3). The intensity of label within the largest antral follicles appeared reduced (Fig. 4) between 20 and $40 \mathrm{~h}$ both over the zona pellucida and the follicular fluid (compare with Fig. 1.) No detectable label was observed over the cumulus cells (Fig. 5).

The injection of hCG initiates the final stages of oocyte maturation, germinal vesicle breakdown and the resumption of meiosis (Fig. 6). Changes in the intensity of silver grains within the preovulatory follicles are shown in Table 1 . Within $8 \mathrm{~h}$, the size of the antrum had increased rapidly with a 
thinning of the follicular wall on the surface of the ovary. Coincident with these changes in the preovulatory follicles (Fig. 6) there was a marked increase in the intensity of label in both the follicular fluid and on the surface of the oocyte (Figs 7, 8 \& 11). The zona pellucida was no longer clearly defined (see Fig. 1) although specific labelling was associated with the oocyte and the egg plasma membrane (Fig. 8). In contrast to the period of stimulation with PMSG, silver grain density was now high over the cumulus cells as well as the granulosa and thecal cells of the follicular wall (Figs 9-10). These changes were not only confined to preovulatory follicles, because in many antral follicles which contained oocytes with a germinal vesicle (Fig. 12) silver grain density was also high within the follicular fluid and on the inner and outer edges of the zona pellucida (Figs 13 \& 14). There was also an increase in the density of label within the oocyte itself (Fig. 13), particularly before germinal vesicle breakdown (Table 1), as well as over the cumulus cells surrounding the oocyte (Fig. 15; see Fig. 5). There was a decline in silver grain density in the components of the preovulatory follicles during the period of first polar body formation (Table 1). Silver grain density of the follicular fluid before ovulation was very similar to that in the extracellular matrix in the ampullae of the oviducts after ovulation (Figs $16 \& 17$ and Table 1), although the oocyte surface still showed some specific labelling. This decrease in the intensity of label could be due to the large increase in fluid volume during the final stages of oocyte maturation or to a shortage of labelled precursor. When $\left[{ }^{3} \mathrm{H}\right]$ glucosamine was injected at the time of the resumption of meiosis $(4 \mathrm{~h}$ after $\mathrm{hCG}$ ), and the mouse autopsied $7 \mathrm{~h}$ later, there was very heavy labelling of the extracellular matrix (Figs $18 \& 19$ ) and a high density of silver grains over the cumulus cells surrounding the recently ovulated egg (Figs $20 \& 21$ ) compared to that found when the label was injected at the same time as the PMSG (Fig. 22). The specific labelling of the oocyte surface was also very pronounced (Fig. 23) although there was no label within the oocyte itself. The zona pellucida of the ovulated egg is not clearly defined by labelling (cf. Fig. 1) and the labelling of the zona pellucida of preantral follicles illustrated in Fig. 19 is relatively light.

\section{Injection of $\left[{ }^{3} \mathrm{H}\right]$ glucosamine for a 2-h period during stimulation with $P M S G$ and $h C G$}

During the period of PMSG stimulation the incorporation of $\left[{ }^{3} \mathrm{H}\right]$ glucosamine into the largest antral follicles was essentially similar to that found when the label was injected with the PMSG although the intensity of label was greater (Table 1). Most of the label was concentrated in the zona pellucida and follicular fluid (Figs $24 \& 25$ ) while the density of silver grains within the zona pellucida of two-layer preantral follicles was relatively low (Fig. 25). No label was observed over the cumulus or granulosa cells (Fig. 26) and the labelling of the oocyte was relatively low. The injection of hCG substantially changed the distribution of label within the preovulatory follicles (Table 1). The resumption of meiosis generally occurs after $4 \mathrm{~h}$ stimulation with hCG. At this time, follicles in different stages of follicular maturation exhibited a different distribution of label within the oocyte-cumulus complex. In those follicles in which the oocyte-cumulus complex was still attached to the follicular wall (Fig. 27) and the cumulus cells adhered tightly to the zona surface, the density of label within the zona pellucida was relatively uniform (Fig. 28), although some of the label was associated with the cumulus and granulosa cells. However, in other more advanced preovulatory follicles in which the oocyte-cumulus complex had detached from the follicular wall, there was a concentration of label on the inner and outer edges of the zona (Fig. 29). This was further accentuated in follicles in which the cumulus cells were beginning to lift away from the zona surface (Fig. 30). The deposition of label on the egg plasma membrane was very characteristic (Fig. 30) and similar to that observed after $8 \mathrm{~h}$ stimulation with hCG (Fig. 8). The activity observed over the cumulus cells and ecm is shown in Figs 31-33. There was a gradual decline in the intensity of label within the folliclular fluid and zona pellucida of the preovulatory follicle between 42 and $50 \mathrm{~h}$ (see Table 1) coincident with an increase in the intensity of label within the cellular components particularly between 4 and $8 \mathrm{~h}$ after the injection of hCG. As ovulation approaches with the extrusion of the first polar body, the rate of incorporation of label into the preovulatory follicle declined 


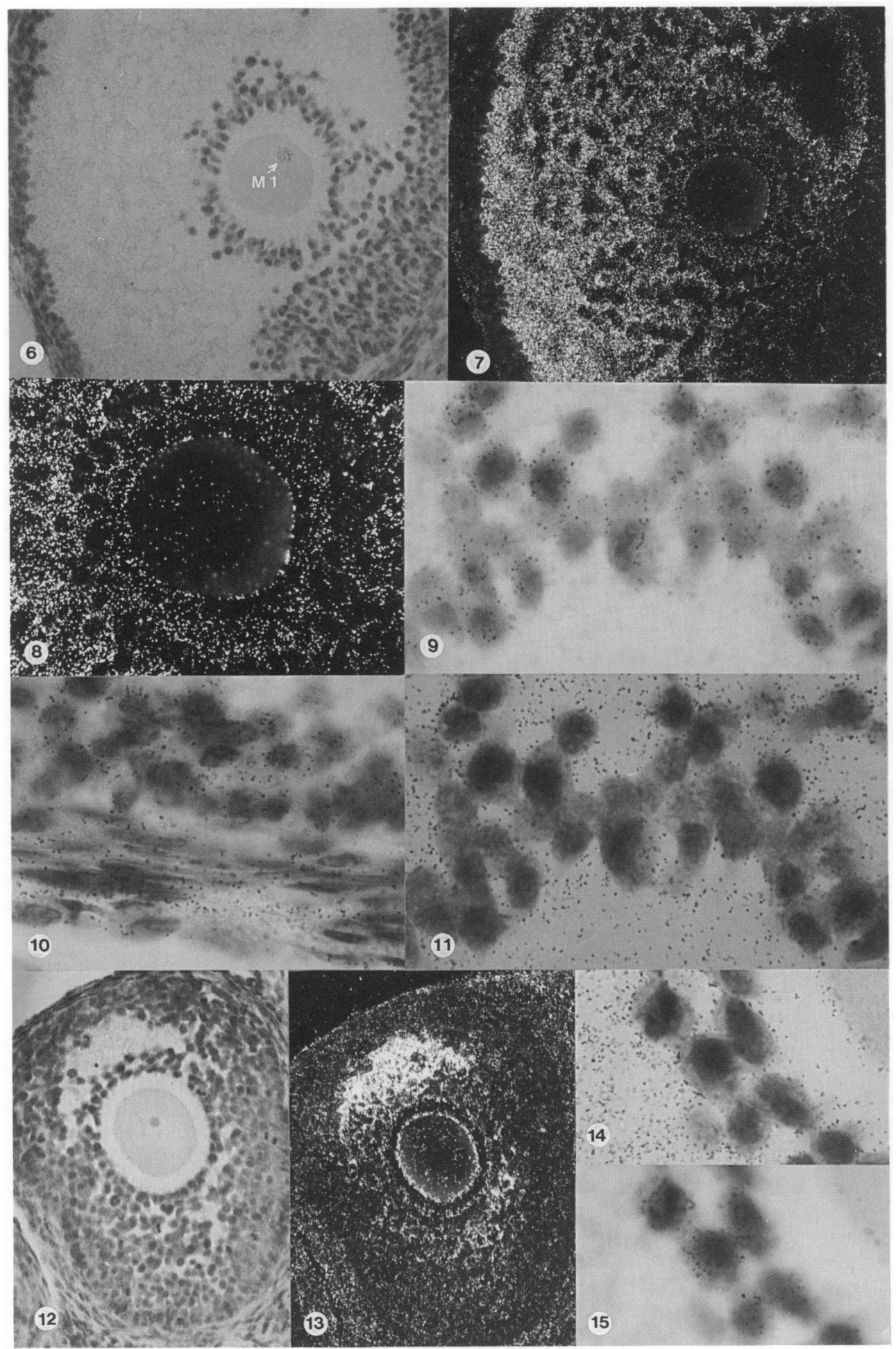


(Figs $34 \& 35$ ). There was a reduction in the intensity of silver grains within the follicular fluid and over the cumulus cells (Figs $36 \& 37$ ) as well as over the granulosa and thecal cells (Table 1). The zona pellucida was no longer clearly defined (Fig. 35) although even during the 2-h incubation period, the surface of the oocyte still showed some specific labelling. If label was injected for a 4-h period at the same time as the hCG, the labelling was generally similar to that observed in Fig. 28, with no specific labelling of the egg surface, but when follicular development was advanced there is again specific labelling of the plasma membrane of the oocyte (Figs 38 \& 39), with a high intensity of label over the cumulus cells and in the follicular fluid.

\section{Discussion}

Our own earlier studies have highlighted the changing structure and histochemical composition within the cumulus-oocyte complex during the final stages of oocyte maturation in response to gonadotrophin treatment (Fowler \& Grainge, 1985; Fowler et al., 1986). The present autoradiographic study using $\left[{ }^{3} \mathrm{H}\right]$ glucosamine served to localize the changes in the distribution of glycoproteins and glycosaminoglycans within the preovulatory follicle after gonadotrophin treatment. It is clear that gonadotrophins have a marked effect on the incorporation and distribution of $\left[{ }^{3} \mathrm{H}\right]$ glucosamine into glycoconjugates in the preovulatory follicles as they do in preantral follicles (Fowler \& Guttridge, 1987). During the period of PMSG stimulation [ ${ }^{3} \mathrm{H}$ ]glucosamine was largely incorporated into glycoconjugates within the follicular fluid and the zona pellucida with almost no uptake of label by the follicular cells. Much of the incorporation within the 2-h period may be into glycoprotein molecules since the turnover of glycoproteins in mouse follicular fluid is relatively fast compared to the renewal of complex sulphated carbohydrates in rabbit follicles (Zachariae, 1957). Longer term labelling may involve the incorporation of $\left[{ }^{3} \mathrm{H}\right]$ glucosamine into glycosaminoglycans

Figs 6-15. $\left[{ }^{3} \mathrm{H}\right]$ Glucosamine was injected at the same time as the PMSG.

Fig. 6. A photomicrograph of a preovulatory follicle $8 \mathrm{~h}$ after the injection of hCG. Note the breakdown of the germinal vesicle and the presence of MI chromosomes. The cumulus cells are no longer tightly apposed to the oocyte surface. Haematoxylin, $\times 245$.

Fig. 7. An autoradiograph of the preovulatory follicle illustrated in Fig. 6. Note the specific labelling on the egg surface. Dark field, $\times 245$.

Fig. 8. A higher magnification of the oocyte in Fig. 7. Dark field, $\times 490$.

Fig. 9. A photomicrograph illustrating the density of label over the cumulus cells of the follicle illustrated in Fig. 6. Haematoxylin, $\times 1225$.

Fig. 10. A photomicrograph illustrating the labelling of the thecal and granulosa cells of the preovulatory follicle illustrated in Fig. 6. Haematoxylin, $\times 1225$.

Fig. 11. A photomicrograph of the cells in Fig. 9 showing the intensity of label with the follicular fluid surrounding the cumulus cells. Haematoxylin, $\times 1225$.

Fig. 12. A large non-ovulatory follicle $8 \mathrm{~h}$ after the injection of hCG. Note the relatively small antrum (see Fig. 6) and the persistence of the germinal vesicle within the oocyte. Haematoxylin, $\times 245$.

Fig. 13. An autoradiograph of Fig. 12. The distribution of label on the inner and outer edges of the zona pellucida contrasts with that observed in Fig. 1. Dark field, $\times 245$.

Fig. 14. A higher magnification of cumulus cells and zona pellucida surrounding the oocyte in Fig. 12 showing the labelling of the follicular fluid. Haematoxylin, $\times 1225$.

Fig. 15. The labelling associated with the cumulus cells in Fig. 14. Haematoxylin, $\times 1225$. 


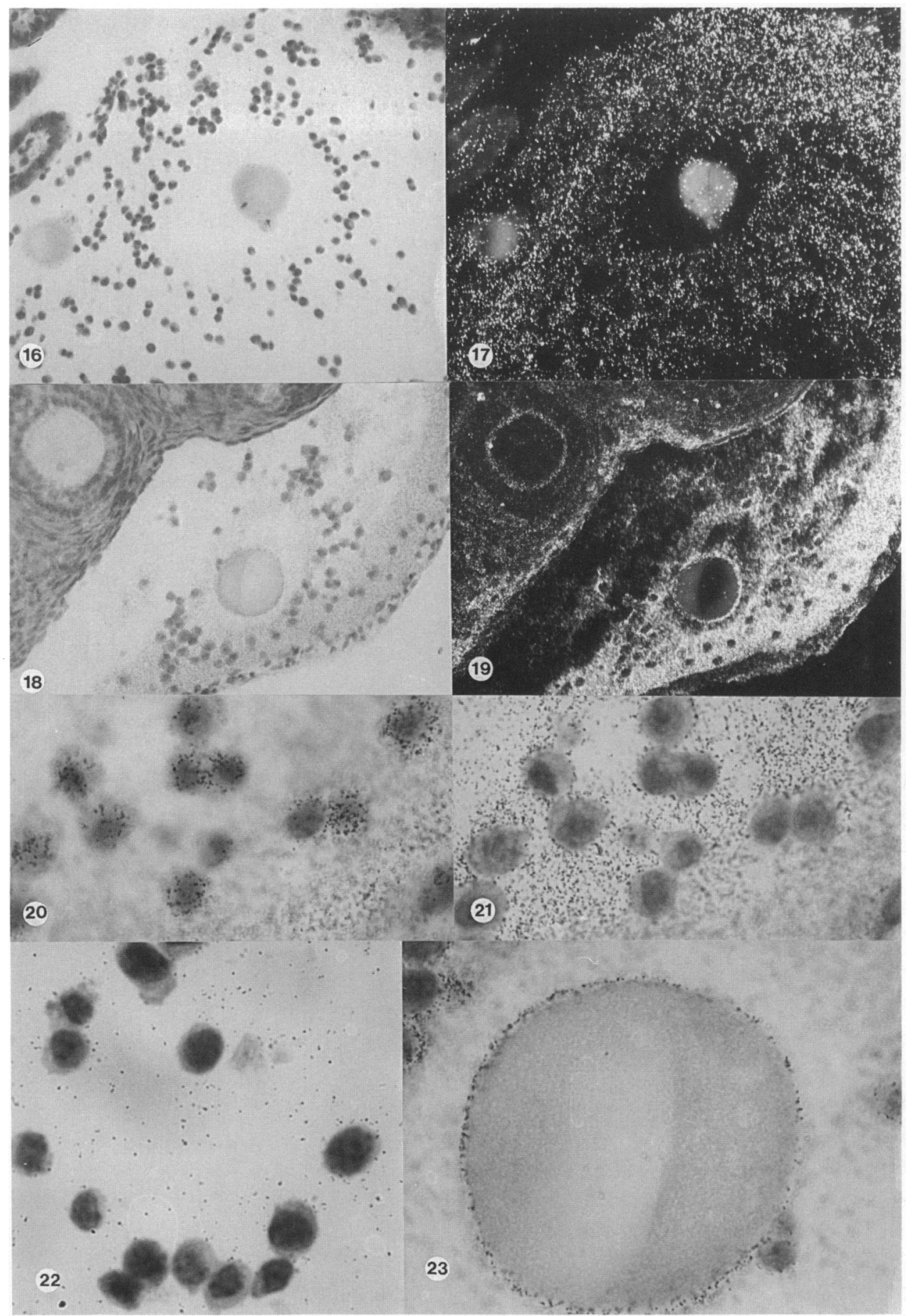


associated with large proteoglycan aggregates. The injection of hCG, which initiates the final stages of oocyte maturation, was characterized by marked changes in the distribution of label within the preovulatory follicle. Between 4 and $8 \mathrm{~h}$ after the injection of hCG the distribution of label within the zona pellucida changed.

During the period of PMSG stimulation, the zona was uniformly labelled but after germinal vesicle breakdown the label became increasingly localized to the outer edge of the zona pellucida and on the inner edge adjacent to the egg plasma membrane especially in short-term $(2 \mathrm{~h})$ exposures to $\left[{ }^{3} \mathrm{H}\right]$ glucosamine. The significance of this change in the distribution of labelled glycoconjugates to the inner and outer surfaces of the zona pellucida after germinal vesicle breakdown is far from clear. The zona pellucida plays a critical role in fertilization because spermatozoa must attach to and pass through the zona pellucida before fusing with the oocyte. The deposition of glucosamine residues on the outer surfaces of the zona pellucida following germinal vesicle breakdown gives substance to the proposal of Shur \& Hall (1982) that, in mice, terminal $N$-acetylglucosamine residues on the zona surface may bind to specific glycosyltransferases located on the sperm surface, because the digestion of mouse zona pellucida by $\beta$ - $N$-acetylglucosaminidase dramatically reduces sperm binding. Pretreatment of capacitated mouse spermatozoa with neuraminidase also inhibits sperm binding to the zona suggesting that sialylated glycoconjugates on the surface of the spermatozoa are also involved in sperm binding (Lambert \& Le, 1984). It seems likely that the complex interaction between the spermatozoon and egg involves more than one receptor because other studies suggest that mannose and fucose may also play a part in sperm-egg binding (Huang et al., 1982; Shalgi et al., 1986).

The build-up of glycoconjugates with $N$-acetylglucosamine residues in the region of the egg plasma membrane after germinal vesicle breakdown could be involved in the attachment of the sperm head to the egg plasma membrane. However, the incorporation of $\left[{ }^{3} \mathrm{H}\right]$ glucosamine into macromolecules located in the region of the oocyte plasma membrane is closely correlated with the

Figs 16, 17 and 22. $\left[{ }^{3} \mathrm{H}\right]$ Glucosamine was injected at the same time as the PMSG.

Fig. 16. A photomicrograph of an ovulated oocyte in the ampullae of the oviduct within 1-2 h after ovulation (i.e. $13 \mathrm{~h}$ after hCG). Note that the 1 st polar body has been extruded and the cumulus cells are widely dispersed. Haematoxylin, $\times 245$.

Fig. 17. An autoradiograph of Fig. 16. Most of the label appears to be associated with the ecm rather than the dispersed cumulus cells. Dark field, $\times 245$.

Figs 18-21 and 23. The label was injected $4 \mathrm{~h}$ after the hCG.

Fig. 18. A photomicrograph of a recently ovulated oocyte on the surface of the ovary with its attendant cumulus cells. Haematoxylin, $\times 245$.

Fig. 19. An autoradiograph of Fig. 18. Note the lack of silver grains in the oocyte itself (see Figs $8 \& 13$ ) and the high density of label associated with the oocyte surface. Dark field, $\times 245$.

Fig. 20. A high magnification of some cumulus cells surrounding the ovulated oocyte in Fig. 18. Haematoxylin, $\times 1225$.

Fig. 21. A photomicrograph of the same cells showing the high silver grain density in the extracellular matrix. Haematoxylin, $\times 1225$.

Fig. 22. A photomicrograph of cumulus cells surrounding the ovulated oocyte illustrated in Fig. 16. Note the relatively low silver grain density in the ecm as compared with Fig. 21, and in lack of label in the cumulus cells (see Fig. 20). Haematoxylin, $\times 1225$.

Fig. 23. A high magnification of the oocyte (Fig. 18) showing the specific association of the silver grains with the oocyte surface. Haematoxylin, $\times 1225$. 


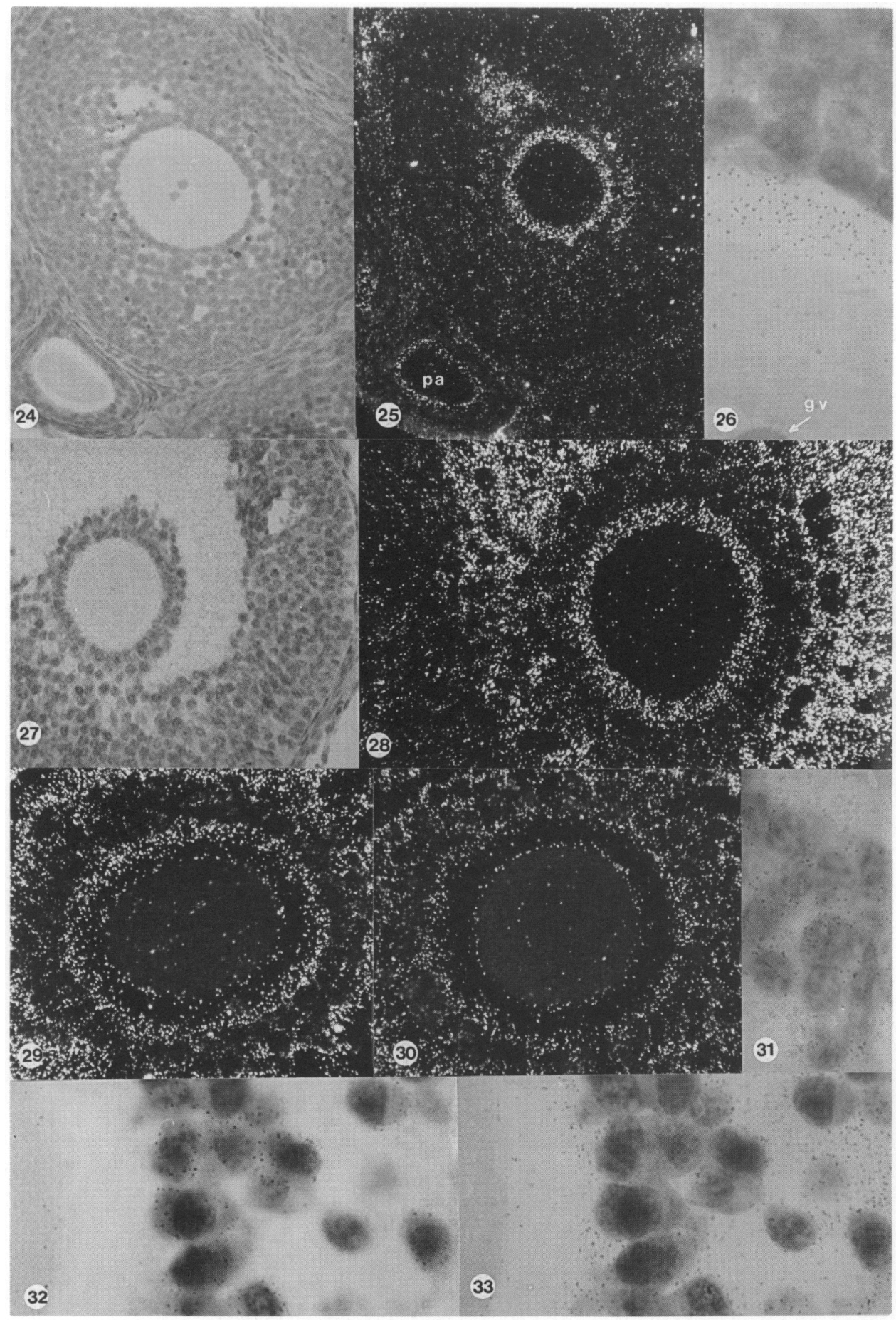


increase in PAS-positive material in this region during the final stages of oocyte maturation (Fowler et al., 1986). It could be that PAS-positive glycoconjugates laid down in the region of the egg plasma membrane may be associated with the cortical granules; cortical granule exocytosis which occurs after fertilization provides the major block to polyspermy (Yanagimachi, 1981). The dramatic decrease in sperm binding caused by cortical granule exudates (Barros \& Yanagimachi, 1971; Wolf \& Hamada, 1977) may be explained if cortical granules are rich in $N$-acetylglucosamine residues which are known to reduce sperm binding dramatically (Ahuja, 1985).

Cortical granule release is implicated in the block to sperm penetration at the zona level, at the level of the egg plasma membrane or at both sites (Wolf \& Hamada, 1977; Gulyas, 1980). Indeed, cortical granule material may reduce the sperm receptor binding of the zona glycoprotein ZP3 purified from zonae pellucidae, which no longer exhibits sperm receptor and acrosome-inducing activities after fertilization (Florman et al., 1984).

The initiation of germinal vesicle breakdown which occurs within $4 \mathrm{~h}$ after the administration of hCG may be a result of changes in the permeability of the zona brought about by a reduction in the glycosaminoglycan content of the zona pellucida (Fowler \& Grainge, 1985) in a manner similar to that observed in the kidney glomerular basement membrane (Kanwar et al., 1980). Other theories for the maintenance of oocytes in the dictyate stage postulate an oocyte maturation preventing factor (OMPF) extracted from granulosa cells (Sato et al., 1986). The authors suggest that the glycosaminoglycan matrix may influence the OMPF action on oocytes. One consequence of the effect of hCG is to stimulate the rapid incorporation of $\left[{ }^{3} \mathrm{H}\right]$ glucosamine into all types of cells within the preovulatory follicle, especially the cumulus cells surrounding the oocyte. The secretions

Figs 24-33. $\left[{ }^{3} \mathrm{H}\right]$ Glucosamine was injected $2 \mathrm{~h}$ before autopsy.

Fig. 24. A developing antral follicle after $40 \mathrm{~h}$ stimulation with PMSG. The oocyte contains a germinal vesicle. Haematoxylin, $\times 245$.

Fig. 25. An autoradiograph of Fig. 24. The silver grain density over the zona pellucida of the preantral follicle $(\mathrm{pa})$ is much lower. Dark field, $\times 245$.

Fig. 26. A high magnification of the labelling of the zona pellucida in Fig. 24. The edge of the germinal vesicle (gv) is just visible. Haematoxylin, $\times 1225$.

Fig. 27. A preovulatory follicle $4 \mathrm{~h}$ after the injection of hCG. This oocyte contained chromosomes at metaphase I. The follicular wall still contained many layers of granulosa cells and the cumulus cells adhere closely to the oocyte. Haematoxylin, $\times 245$.

Fig. 28. An autoradiograph of the oocyte and cumulus mass illustrated in Fig. 27. The zona pellucida and follicular fluid are densely labelled. Dark field, $\times 290$.

Fig. 29. An autoradiograph of the oocyte-cumulus complex within another preovulatory follicle $4 \mathrm{~h}$ after the injection of hCG. Metaphase I chromosomes were clearly visible in this oocyte and the cumulus cells still adhered tightly to the surface of the zona pellucida although the cumulus mass was detached from the follicular wall. Dark field, $\times 290$.

Fig. 30. An autoradiograph of a more advanced follicle in which the cumulus mass is completely detached from the follicular wall and the cumulus cells are just beginning in some places to detach from the surface of the zona pellucida. The process apparent in Fig. 29 is further accentuated in this oocyte in that the inner and outer edges of the zona pellucida are the most heavily labelled. Dark field, $\times 290$.

Fig. 31. Cumulus cells surrounding the oocyte illustrated in Fig. 27. Haematoxylin, $\times 1225$.

Fig. 32. Cumulus cells surrounding the oocyte in Fig. 29. Haematoxylin, $\times 1225$.

Fig. 33. This figure illustrates the same cumulus cells showing the density of label in the zona pellucida and follicular fluid. Haematoxylin, $\times 1225$. 


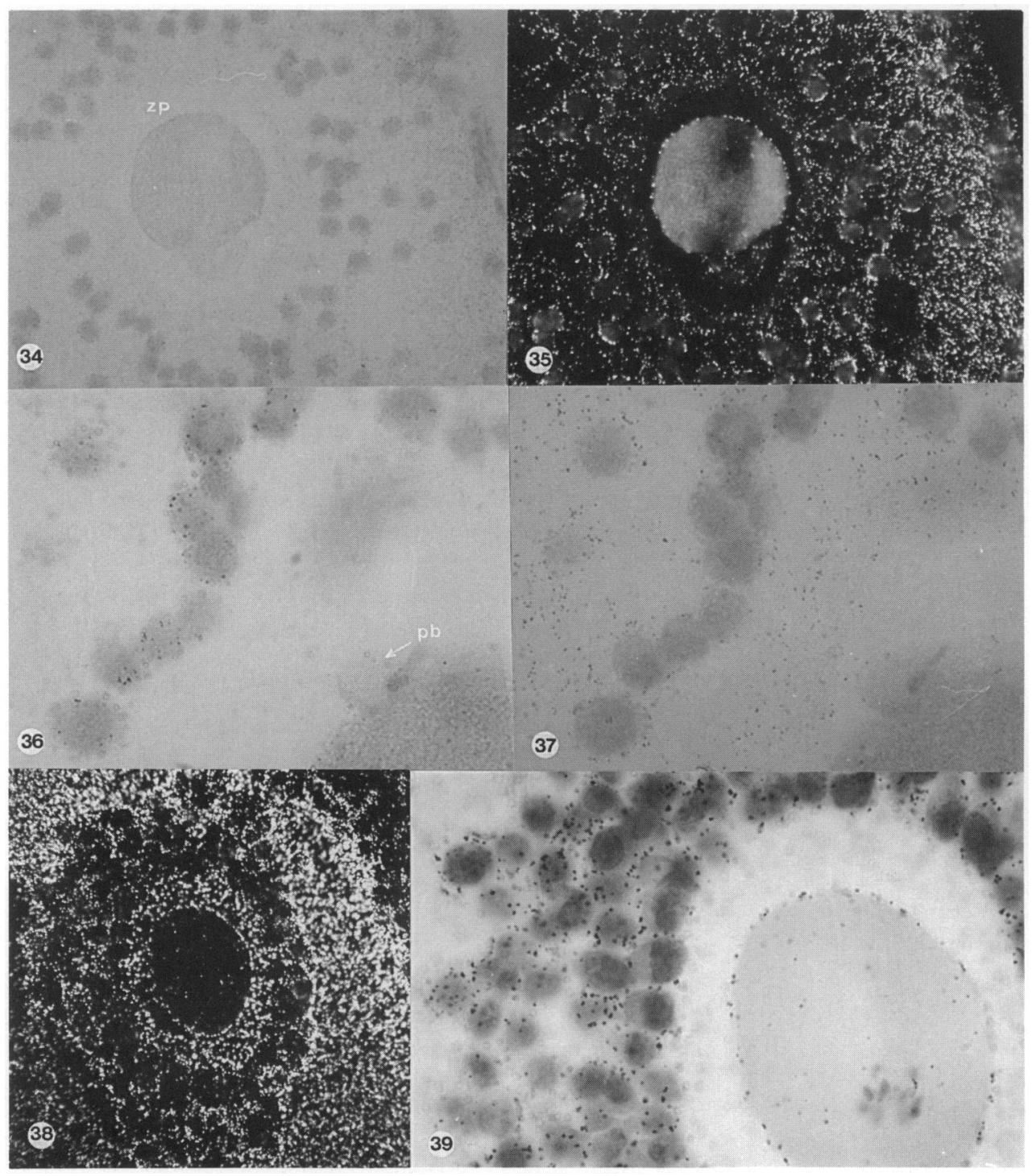

Figs 34-37. $\left[{ }^{3} \mathrm{H}\right]$ Glucosamine was injected $2 \mathrm{~h}$ before autopsy.

Fig. 34. An oocyte and its attendant cumulus cells in a preovulatory follicle $\sim 1 \mathrm{~h}$ before ovulation. The outline of the zona pellucida is just visible (zp) and the first polar body had been extruded. The cumulus cells are fairly widely dispersed. Haematoxylin, $\times 490$.

Fig. 35. An autoradiograph of Fig. 34. There is no label in the oocyte or perivitelline space and no specific labelling of the zona pellucida. There was some specific labelling of the oocyte surface and over the cumulus cells in addition to the labelling of the extracellular matrix. Dark field, $\times 1225$.

Fig. 36. High magnification showing the labelling of the cumulus cells around the oocyte illustrated in Fig. 34. Note the presence of the 1st polar body (pb). Haematoxylin, $\times 1225$.

Fig. 37. A photomicrograph of the same cumulus cells showing the labelling density in the extracellular matrix. Haematoxylin, $\times 1225$. 
Fig. 38. An autoradiograph of a preovulatory follicle $4 \mathrm{~h}$ after the injection of hCG in which the label was injected with the hCG. Note the high density of label in all the follicular components except the oocyte itself. Dark field, $\times 490$.

Fig. 39. A higher magnification of the labelling demonstrated in Fig. 38, showing the specificity of label on the oocyte surface and the high density of label within the cumulus cells surrounding the oocyte. Note the presence of metaphase I chromosomes in the egg itself. Haematoxylin, $\times 1225$.

from these cells are rich in carbohydrate-protein macromolecules and these glycoconjugates could influence the OMPF factor, as postulated by Sato et al. (1986). The rapid increase in silver grain density over the granulosa and cumulus cells of the preovulatory follicles after hCG stimulation is probably largely associated with the mucification processes and the synthesis of hyaluronic acid, a non-sulphated glycosaminoglycan; hCG or LH has generally been shown to inhibit the production of sulphated glycosaminoglycans (Gebauer et al., 1978).

Autoradiography which utilizes the dynamic activity of an in-vivo system has been used to investigate the synthesis and distribution of labelled macromolecules during oocyte maturation. It is proposed to extend these studies to investigate the role of a variety of labelled carbohydrates during oocyte maturation, fertilization and the block to polyspermy, because there is increasing evidence that carbohydrates play a critical role in all these processes.

I thank Professor Matt Kaufman and Professor Robert Edwards for their encouragement during the course of this work, and Mrs Barratt for technical assistance. The study was undertaken with the support of a research grant from Birthright (held jointly by R. E. F. and M. H. Kaufman).

\section{References}

Ahuja, K. (1985) Carbohydrate determinants involved in mammalian fertilization. Am. J. Anat. 174, 207-223.

Ax, R.L. \& Ryan, R.J. (1979a) The porcine ovarian follicle IV. Mucopolysaccharides at different stages of development. Biol. Reprod. 20, 1123-1132.

Ax, R.L. \& Ryan, R.J. (1979b) FSH stimulation of $\left[{ }^{3} \mathrm{H}\right]$ glucosamine incorporation into proteoglycans by porcine granulosa cells in vitro. $J$. clin. Endocr. Metab. 49, 646-648.

Barros, C. \& Yanagimachi, R. (1971) Induction of the zona reaction in golden hamster egg by cortical granule material. Nature, Lond. 233, 268-269.

Bleil, J.D. \& Wassarman, P.L. (1980) Structure and function of the zona pellucida: identification and characterization of the proteins of the mouse oocyte's zona pellucida. Devl Biol. 761, 185-202.

Bleil, J.D. \& Wassarman, P.L. (1983) Sperm egg interactions in the mouse; sequence of events and induction of the acrosome reaction by a zona pellucida glycoprotein. Devl Biol. 95, 317-324.

Da Silva Sasso, W. (1959) Existence of hyaluronic acid in the zona pellucida of the rabbit's ovum. Acta anat. 36, 352-357.

Edwards, R.G. \& Gates, A.H. (1959) Timing of the stages of the maturation divisions, ovulation, fertilization and the first cleavage of eggs of adult mice treated with gonadotrophins. J. Endocr. 19, 292-304.

Eppig, J.J. (1979) FSH stimulates hyaluronic acid synthesis by oocyte cell complexes from mouse preovulatory follicles. Nature, Lond. 281, 483-484.
Eppig, J.J. (1981) Ovarian glycosaminoglycans: evidence for a role in regulating the response of oocytecumulus cell complex to FSH. Endocrinology 108, 1992-1994.

Florman, H.M., Bechtol, K.B. \& Wassarman, P.M. (1984) Enzymatic dissection of the functions of the mouse egg receptor for sperm. Devl Biol. 106, $243-255$.

Fowler, R.E. \& Grainge C. (1985) A histochemical study of the changes occurring in the protein-carbohydrate composition of the cumulus-oocyte complex and zona pellucida in immature mice in response to gonadotrophin stimulation. Histochem. J. 17, 1235-1249.

Fowler, R.E. \& Guttridge, K. (1987) An autoradiographic study using $\left[{ }^{3} \mathrm{H}\right]$ glucosamine of gonadotrophin regulation of proteoglycan and glycoprotein synthesis in developing mouse follicles. J. Reprod. Fert. 81, 415-426.

Fowler, R.E., Kaufman, M.H. \& Grainge, C. (1986) The secretions of the cumulus-oocyte complex in relation to fertilization and early mouse embryonic development; a histochemical study. Histochem. J. 18, 541-550.

Gebauer, H., Lindner, H.R. \& Amsterdam, A. (1978) Synthesis of heparin like glycosominoglycans in rat ovarian slices. Biol. Reprod. 18, 350-358.

Gulyas, B.J. (1980) Cortical granules of mammalian eggs. Int. Rev. Cytol. 63, 357-392.

Haddad, A. \& Nagai, M.E.T. (1977) Radioautographic study of glycoprotein biosynthesis and renewal in the 
ovarian follicles of mice and the origin of the zona pellucida. Cell Tiss. Res. 177, 347-369.

Huang, T.T.F., Ohzu, E. \& Yanagimachi, R. (1982) Evidence suggesting the L-fucose is part of a recognition signal for sperm-zona pellucida attachment in mammals. Gamete. Res. 5, 355-361.

Lambert, H. \& Le, A.V. (1984) Possible involvement of sialylated component of the sperm plasma membrane in sperm-zona interaction in the mouse. Gamete. Res. 10, $153-168$.

Kang, Y. (1974) Development of the zona pellucida in the rat oocyte. Am. J. Anat. 139, 533-544.

Kanwar, Y.S., Linker, A. \& Farquier, K.M.G. (1980) Increasing permeability of the glomerular basement membrane to ferritin after removal of glycosaminoglycans (heparan sulphate) by enzyme digestion. $J$. Cell Biol. 86, 688-693.

McDowell, E.M. \& Trump, B.F. (1976) Histologic fixatives suitable for diagnostic light and electron microscopy. Archs Path. Lab. Med. 100, 405-414.

Oakberg, E.F. \& Tyrell, P.D. (1975) Labelling the zona pellucida of the mouse oocyte. Biol. Reprod. 12, 477-482.

Sato, E., Ueno, H. \& Koide, S.S. (1986) Mouse oocyte maturation modulated by a granulosa cell factor and by heparin and heparan sulphate. Gamete Res. 13, $115-124$.

Shalgi, R., Matityahu, A. \& Nebel, L. (1986) The role of carbohydrates in sperm-egg interaction in rats. Biol. Reprod. 34, 446-452.

Shimizu, S. \& Yamada, K. (1986) The cytochimistry of glycoconjugates in the zona pellucida of murine ovarian oocytes and two-cell embryos. Histochem. J. 18, 357-363.

Shimizu, S., Tsuji, M. \& Dean, J. (1983) In vitro biosynthesis of three sulphated glycoproteins of murine zonae pellucidae by oocytes grown in follicle culture. J. biol. Chem. 258, 5858-5863.

Shur, B.D. \& Hall, N.G. (1982) A role for mouse surface galactosyl transferase in sperm binding to the egg zona pellucida. J. Cell Biol. 95, 574-579.

Tadano, Y. \& Yamada, K. (1978) The histochemistry of complex carbohydrates in the ovarian follicles of adult mice. Histochemistry 57, 203-215.

Wolf, D.P. \& Hamada, M. (1977) Induction of zonal and egg plasma membrane blocks to sperm penetration in mouse eggs with cortical granule exudate. Biol. Reprod. 17, 350-354.

Yanagimachi, R. (1981) Mechanisms of fertilization in mammals. In Fertilization and Embryonic Development in vitro, pp. 81-82. Eds L. Mastrioianni \& J. D. Biggers. Plenum, New York.

Yanagashita, M. \& Haskall, V.C. (1979) Biosynthesis of proteoglycans by rat granulosa cells cultured in vitro. J. biol. Chem. 254, $12355-12364$.

Yanagashita, M., Rodbard, D. \& Haskall, V.C. (1979) Isolation and characterization of proteoglycans from porcine ovarian follicular fluid. J. biol. Chem. 254, 911-920.

Yanagashita, M., Haskall, V.C. \& Rodbard, D. (1981) Biosynthesis of proteoglycans by rat granulosa cells cultured in vitro: modulation by gonadotrophins, steroid hormones, prostaglandins and a cyclic nucleotide. Endocrinology 109, 1641-1649.

Zachariae, F. (1957) Studies on the mechanism of ovulation: autoradiographic investigation of the uptake of radioactive sulphate $\left({ }^{35} \mathrm{~S}\right)$ into the ovarian follicular, mucopolysaccharides. Acta endocr., Copenh. 26, 215-224.

Received 5 November 1987 